\title{
RESPIRATORY TRACT CRYPTOSPORIDIOSIS IN IMMUNOSUPPRESSED RAT IS ASSOCIATED WITH AN EPITHELIAL METAPLASIA
}

\author{
ROUSSEL F.*, LEMETEIL D.**, FAVENNEC L. ${ }^{* *},{ }^{* * * *}$, TAYOT J.***, BALLET J.J.**** \& BRASSEUR P.**
}

Summary :

Cryptosporidium parvum is an opportunistic protozoa that chronically infects the digestive tract of immunocompromised hosts. Respiratory cryptosporidiosis, which was reported in AIDS patients, is an uncommon feature of mammalian cryptosporidiosis models. In this study, we document the respiratory lesions observed in an immunosuppressed rat model of cryptosporidiosis. Twenty rats were immunosuppressed with corticosteroids and low protein diet. They were challenged intratracheally with 106 C. parvum sporozoites. Lungs and ileums were examinated on D3, D6, D 10, D14. On D 10 and D14, C. parvum were present in the respiratory tract of all animals in association with the progressive appearance of an immature malpighian metaplasia. On D14, an intestinal infection was also detected in 2/4 animals. The respiratory tract appears to be a fully permissive area for the protozoa in immunosuppressed rats. Introduction of parasites on the respiratory mucosa seems a requisite to induce respiratory cryptosporidiosis. This experimental protocol yields a low mortality rate, and so modelizes late and/or chronic stages of respiratory cryptosporidiosis.

KEY WORDS : immunosuppression. corticosteroids. Cryptosporidium parvum. rat. respiratory tract.

Abbreviations: DMEM : Dulbecco Modified Eagle Medium. D : Day.

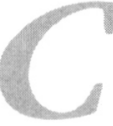

ryptosporidium parvum is a protozoa responsible for opportunistic chronic infection in immunocompromised hosts with an intestinal tropism (Current and Garcia, 1991). Extra digestive and extra biliary manifestations were uncommonly observed in man, and most of them involve the respiratory tract (Brady et al., 1984; Forsacs et al., 1983; Goodstein et al., 1989; Hojyling and Jensen, 1988; Kibbler et al., 1987; Kocoshis et al., 1984; Ma et al., 1984; Travis et al., 1990; Weitz et al., 1986). In birds, C. baileyi is responsible for respiratory infections (Blagburn et al., 1987). Respiratory cryptosporidiosis

\footnotetext{
* Laboratoires d'Histologie, ** Laboratoire de Parasitologie Expérimentale, ${ }^{* * *}$ Laboratoire d'Anatomie Pathologique B, Groupe de recherches ERPUR, CHU de Rouen F-76000.

${ }^{* * * *}$ Laboratoire d'Immunologie et d'Immunopathologie, CHU de Caen, F- 14033.

Correspondance : Philippe Brasseur, Laboratoire de Parasitologie, Hôpital Charles Nicolle, Centre Hospitalier Universitaire, F-76031 Rouen cédex. Tél. : 35088015 - Fax : 35088017.
}

Résumé : LA CRYPTOSPORIDIOSE PULMONAIRE DU RAT IMMUNODÉPRIMÉ EST ASSOCIÉE À UNE MÉTAPLASIE ÉPITHÉLIALE

Cryptosporidium parvum est un protozoaire opportuniste responsable d'infections chroniques de l'appareil digestif chez les hôtes immunodéprimés. Une cryptosporidiose respiratoire a été décrite chez des patients atteints de SIDA mais est une manifestation rare de la cryptosporidiose expérimentale des mammifères. Nous décrivons ici les lésions respiratoires d'un modèle de cryptosporidiose chez le rat immunodéprimé. Vingt rats immunodéprimés par traitement aux corticoïdes et régime carencé en protéines ont été infestés par voie intratrachéale à l'aide de $10^{6}$ sporozoïtes de C. parvum. Les poumons et les iléons sont étudiés à J4, J6, J10, et 114 après l'infestation. A J10 et à J14, C. parvum est retrouvé dans l'appareil respiratoire de tous les animaux, et sa présence est associée à l'apparition progressive d'une métaplasie malpighienne immature. A J14, deux rats sur quatre présentent également une cryptosporidiose intestinale. L'arbre bronchique apparaît donc réceptif à C. parvum chez le rat immunodéprimé, et la voie aérienne d'introduction des parasites au niveau de la muqueuse respiratoire semble indispensable au développement d'une cryptosporidiose respiratoire. Le protocole décrit ici, qui s'accompagne d'un faible taux de mortalité, constitue un modèle qui reproduit les stades tardifs et/ou chroniques de la cryptosporidiose respiratoire.

MOTS CLES : immunosuppression. corticostéroïdes, Cryptosporidium parvum. rat. appareil respiratoire.

was not often reported in mammal models (Meulbroek et al., 1991).

In this study, we document the lesions observed in a immunosuppressed rat model of respiratory cryptosporidiosis.

Sprague Dawley rats weighting between 300 and $350 \mathrm{~g}$ and free of C. parvum infection were immunosuppressed as previously described (Brasseur et al.,1988). Briefly, rats were fed a low protein $(7 \%)$ diet (exclusively white bread) and given a regimen of $25 \mathrm{mg}$ of hydrocortisone acetate injected subcutaneously twice weekly, five weeks before and two weeks after C. parvum challenge (i.e. from D35 to D14). Sulfamethoxazole $(30 \mathrm{mg} / \mathrm{kg} / \mathrm{day})$ and trimethoprim (6mg/kg/day) (Eusaprim ${ }^{\circledR}$, Wellcome, France) were given in drinking water from D35 to D3 to avoid Pneumocystis carinii infection. Animals were challenged at Do with human C.parum sporozoites. Oocysts were obtained from the stools of a 


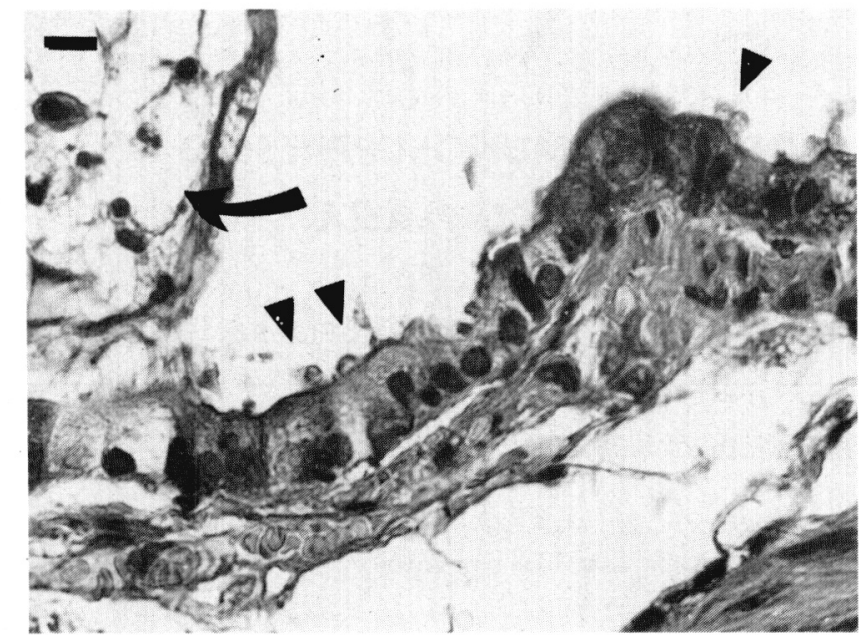

Fig. 1. - Large bronchi at D10. Cilia are absent from many cells. Some of them are bearing apical parasites, closely resembling the intestinal parasitism (arrowheads). Some foamy material (arrow) containing macrophages is filling some bronchial lumens. (Stain Hematein-Eosin-Saffron. Bar: $20 \mathrm{~mm}$.)

single AIDS patient attending the medical clinic of the hospital, purified in a sucrose gradient, and excystated as previously described (Buraud et al., 1991). Parasites in suspension were washed in DMEM and sporozoites were separated from oocysts by filtration through $5 \mu \mathrm{m}$ filters. Seventeen animals were challenged intratracheally with $10^{6}$ sporozoites. The trachea of anaesthetized animals was punctured with a $18 \mathrm{G}$ needle. A $22 \mathrm{G}$ catheter was inserted through the needle and blocked in a medium size bronchus of the right lung, and sporozoites were instillated in 200 $\mu \mathrm{l}$ warm saline. In three control animals, a sham instillation (saline) was performed. At D2, two control and 16 challenged animals survived. They were randomized for programmed sacrifices at D3, D6, D10, and D14. Oocysts shedded in stools were counted as previously (Heine, 1982; Brasseur et al., 1988). Control rats were killed at D14. All animals were sacrificed by ether overdose. The trachea, the lungs, the terminal portion of the ileum were fixed in $10 \%$ buffered paraformaldehyde, embedded in paraffin and sectionned $(4 \mu \mathrm{m})$. Sections were stained with Hematein-Eosin-Saffron.

On D3, no oocyst was detected in stools. A few parasites were observed in the respiratory tract of two out of four rats. They appeared tightened to the cilia of the respiratory epithelial cells. No C. parvum was seen in the ileum.

On D6, some parasites were seen in the trachea of $2 / 4$ rats. Oocysts were present in the feces of $1 / 4$ animal, and small numbers of $C$. parum oocysts were also observed in the ileal mucosa.

On D10 (Fig. 1), C. parvum were present in the respiratory tract of $4 / 4$ rats. Their presence was restricted

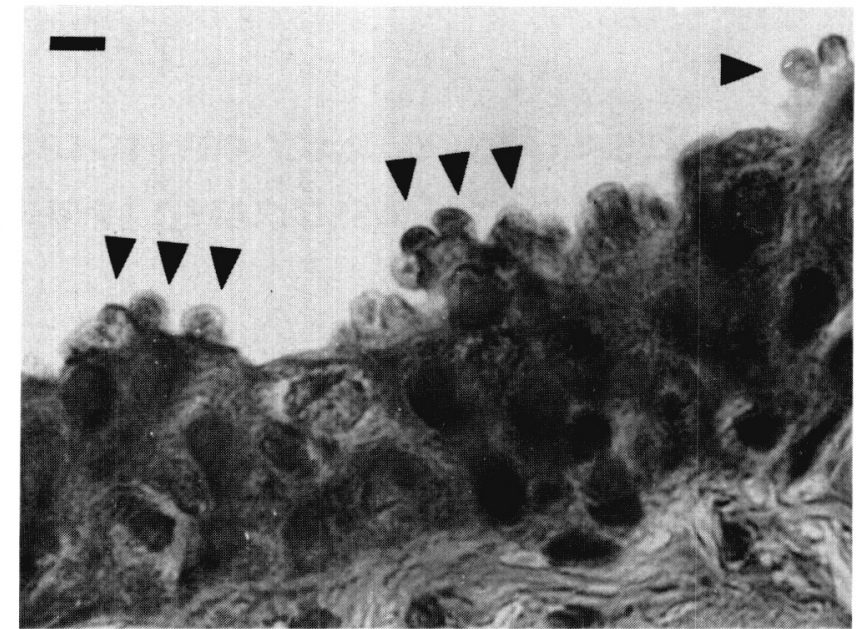

Fig. 2. - Trachea at D14. The respiratory epithelium is metaplastic The apical cells are bearing numerous parasites (arrowheads) (Stain : Hematein-Eosin-Saffron. Bar: $10 \mathrm{~mm}$.)

to the trachea and the main bronchus. In one animal, a foamy material filled the bronchial lumens. The parasites were scarce in three animals, in one rat however, high densities of C. parvum were locally found in both the respiratory tract and the ileum, and associated with low grade oocyst shedding

On D14 (Fig. 2) very high densities of C. parvum were found in the respiratory tracts of $3 / 4$ animals, of which two exhibited parasites in the ileum and shed oocysts in the stools. Parasites were mainly located in the epithelium of the trachea, and of the hilar and lobar bronchi. In the proximal territories, the density of parasites was high. The epithelium bearing the parasites was transformed with immature, non keratinizing, malpighian metaplasia (Fig. 2). Densities of parasites was much lower in zones with residual ciliated cells. In more distal bronchi, epithelial cells were characterized by a patchy loss of apical ciliary expensions. Some parasites were attached on residual cilia. The alveolar related areas were filled with a retentional foamy material containing macrophages. In one animal very low numbers of parasites were seen in the respiratory tract, and the aspect was close from what was observed on D10.

Non specific findings consisted mainly of aspergillomas : $1 / 4$ at D3, $1 / 4$ at D10 and 2/4 at D14. A pleural involvement was observed in $2 / 4$

In our previous experiments, respiratory infestation of digestive origin was never observed in more than one thousand rats challenged per os. For the study of respiratory cryptosporidiosis, we have designed an experimental protocol which required intra-bronchic sporozoite instillation, and resulted in a respiratory infection in $4 / 4$ animals. Thus introduction of para- 
sites on the respiratory mucosa seems a requisite to induce respiratory cryptosporidiosis.

In 2/4 animals, an intestinal infection was also detected. The occurence of a digestive infestation from the respiratory tract can be considered as an evidence of complete intrabronchic parasite cycles since a purified sporozoite preparation was administered intratracheally, and it has been shown that sporozoites per os do not infect the ileum (Riggs and Perryman, 1987). The presence of some contaminating oocysts in sporozoite inocula cannot be excluded however. The time interval before the appearance of parasites in the feces was longer than after per os challenge, which is also consistent with the ingestion of oocysts from the trachea and further development of the parasite in the gut.

Altogether data confirm that the respiratory tract is a fully permissive area for C. parvum. In our model, the permissive territory consists more specifically of ciliated respiratory epithelium. Persisting Cryptosporidium infestation was associated with the progressive appearance of an immature malpighian metaplasia (D10, D14). Such lesions were not present in normal and immunosuppressed rats (Brasseur et al., 1988). Malpighian metaplasia is generally considered as a response to local irritations and it is remarkable that in infected rats, metaplastic areas exhibited the highest parasite density. Thus metaplastic process does not seem to contribute to protection.

In our model, the development of the bronchic infection seemed slower than in the rat model of Meulbroek et al. (1991). This was presumably a consequence of the use of sporozoites instead of oocysts. Our protocol yields a low mortality rate, and modelizes late and/or chronic stages of respiratory cryptosporidiosis. In both models, data indicate that it is possible to mimick features of the human respiratory cryptosporidiosis in experimental animals.

\section{ACKNOWLEDGEMENTS}

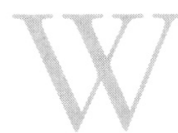

e thank Mrs J. Elouard for her skilful technical assistance. The work was supported by grants from ANRS (1993) and a subvention from Lions' Club, Deauville-Trouville and Fondation Luc, Deauville, France. cryptosporidiosis in acquired immune deficiency syndrome. Journal of the American Medical Association, 1984, 252, 89-90.

Brasseur P., Lemeteil D. \& Ballet J.J. Rat model for human cryptosporidiosis. Journal of Clinical Microbiology, 1988, 26, 1037-1039.

Buraud M., Forget E., Favennec L., Bizet J., Deluol A.M. \& Gobert J.G. Sexual stage development of cryptosporidia in the $\mathrm{CaCO}_{2}$ cell line. Infection and Immunity, 1991, 59 , 4610-4613.

Current W.L. \& Garcia L.S. Cryptosporidiosis. Clinical Microbiology Reviews, 1991, 4, 325-58.

Forsacs P., Tarshis A., Ma P., Federman M., Mele L., Silverman M.L. \& SheA J.A. Intestinal and bronchial cryptosporidiosis in an immunodeficient homosexual man. Annals of Internal Medicine, 1983, 99, 793-794

Goodstein R.F., Colombo C.S., Illfelder M.A. \& Skaggs R.E. Bronchial and gastrointestinal cryptosporidiosis in AIDS. Journal of the American Osteopathic Association, 1989, 89, 195-197.

HeIne J. Eine einfache nachweismethode für Kryptosporidien im Kot. Zentralblatt für Veterinaermedizin, 1982, 29, 324-327.

Hojyling N. \& Jensen B.N. Respiratory cryptosporidiosis in HIV-positive patients. The Lancet, 1988, ii , 590-591.

Kibbler C.C., Smith A., Hamilton-Dutoit S.J., Milburn H., Pattinson J.K. \& Prentice H.G. Pulmonary cryptosporidiosis occuring in a bone marrow transplant patient. Scandinavian Journal of Infectious Disease, 1987, 19, 581-584.

Kocoshis S.A., Cibull M.L., Davis T.E., Hinton J.T., Seip M. \& BANWELl J.G. Intestinal and pulmonary cryptosporidiosis in an infant with severe combined immune deficiency. Journal of Pediatric Gastroenterology and Nutrition, 1984, 3, 149-157

Ma P., Villanuev T.G., Kaufman D. \& Gillooley J.F. Respiratory cryptosporidiosis in the AIDS. Journal of the American Medical Association, 1984, 252, 1298-1301.

Meulbroek J.A., Novilla M.N. \& Current W.C. An immunosuppressed rat model of respiratory cryptosporidiosis. Journal of Protozoology, 1991, 38, 113S-115S.

Riggs M.W. \& PERryman L.E. : Inactivation and neutralization of Cryptosporidium parvum sporozoïtes. Infection and Immunity, 1987, 55, 2081-2087.

Travis W.D., Schmidt K., Maclowry J.D., Masur H., CONDRON K.S. \& FOjo A.T. Respiratory cryptosporidiosis in a patient with malignant lymphoma. Archives of Pathology and Laboratory Medicine, 1990, 114, 519-522.

Weitz J.C., Tassara R., Munoz P., Mercado R. \& Attias R. : Cryptosporidiosis del aparato respiratorio. Revista Medica de Chile, 1986, 114, 691-692.

Accepté le 13 octobre 1994

\section{REFERENCES}

Blagburn B.L., Lindsay D.S., Giambrone J.J., Sundermann C.A. \& Hoerr F.J. Experimental cryptosporidiosis in broiler chickens. Poultry. Science, 1987, 66, 442-449.

Brady E.M., Margolis M.L. \& Korzeniowski O.M. Pulmonary 